\title{
The Development of Guidance Counselling Program through Teaching and Learning Activities for Improving Self-Determination of Students with Intellectual Disability
}

\author{
Jon Efendi \\ Universitas Negeri Padang, Indonesia \\ Email: jofipasi@yahoo.com
}

\begin{abstract}
The autonomy of mild intellectually disabled children is their capabilities to help themselves (self-help). The result of this research is a teacher program which guides autonomy for the mild intellectually disabled students. The research was conducted through the action research approach resulting in "Autonomy Guidance Program" which was arranged collaboratively with teachers of SPLB-C YPPLB Cipaganti Bandung, and then was examined through a seminar. Autonomy guidance that is provided to mild intellectually disabled students are introduction to their characteristics, self-care, plan their daily activities, guidance to do activities consequently, guidance to make a decision, and practice to think positively. The implementation through some practices that were started at low level, consecutively, give guidance, motivation and control that need the participation and cooperation of students' parents, teachers, and other experts.
\end{abstract}

Keywords: autonomy, intellectual handicap children, guidance and counseling

\section{INTRODUCTION}

Facts show that many of special school outputs are not independent in performing daily activities. The purpose of guidance in special school, specifically for students with intellectual disability (SLB-C) is to: (a) conquer the difficulties in taking care of themselves, (b) conquer the difficulties in adjusting to the school environment, family/community and the work/career environment, (c) conquer the difficulties in distributing ability to follow education/training and work/career, (d) use their abilities to get the skills and competence to work optimally (Depdikbud, 1987).

Research by Ahman (1998) put the development task as a goal for guidance. Accordiing to the data and the results of the research that has been conducted, the researchers wanted to uncover the guidance in SLB-C Cipaganti Bandung through a research. The definitions of Counseling and Guidance Development according to Muro and Kottman (1995) are: (a) Guidance and counseling are needed by all children; (b) Developmental guidance and counseling has a focus on children's learning; (c) Counselors and teachers are cofunctionaries in developmental guidance programs; (d) An organized and planed curriculum is a vital part of developmental guidance; (e) Developmental guidance is concerned with selfacceptance, self-understanding, and self-enhancement; (f) Developmental guidance and counseling focus on the encouragement process; (g) Developmental guidance acknowledges directional development rather than definitive ends; (h) Developmental guidance, while team oriented, requires the services of a trained professional counselor; (i) Developmental guidance is concerned with early identification of special needs; (j) Developmental guidance is concerned with the psychology of use; (k) Developmental guidance has foundations in child psychology, child development, and learning theory; (1) Developmental guidance is both sequential and flexible.

The pusrposes of the development of Guidance and Counseling are to: (a) Instill and develop the habit and attitude to be faithful and devoted to God; (b) Develop a conscience, morals and values as guidelines for behavior; (c) Develop the basic skills of reading, writing, and arithmetic; (d) Learn simple physical skills which are required in daily life; (e) Learn to get along and work in peer groups; (f) Learn to be an independent person; (g) Build an attitude of healthy life for yourself and the environment; (h) Develop necessary concepts in everyday life; (i) Learn to run a social role in accordance with gender; (j) Develop a positive attitude towards the groups and social institutions.

The contents of the development of guidance and counseling according to Muro and Kottman (1995), are the guidance for material development program in Elementary School such as: self-esteem, motivation to get achievement, decisitom-making, goal-setting, and planning skills, problem-solving skills, interpersonal effectiveness, communication skills, cross-cultural effectiveness, responsible-behavior. 
Table 1. Student with intellectual disability classify

\begin{tabular}{|c|c|c|c|}
\hline Organization & $\begin{array}{l}\text { Generic } \\
\text { Term }\end{array}$ & Levels & $\begin{array}{l}\text { IQ Range } \\
\text { for Level }\end{array}$ \\
\hline $\begin{array}{l}\text { American Asso- } \\
\text { ciation on Men- } \\
\text { tal Deficiency. }\end{array}$ & $\begin{array}{l}\text { Mental } \\
\text { Retarda- } \\
\text { tion }\end{array}$ & $\begin{array}{l}\text { Mild } \\
\text { Moderate } \\
\text { Severe } \\
\text { Profound }\end{array}$ & $\begin{array}{l}50-55 \text { to } \\
\text { approx } 70 \\
35-40 \text { to } \\
50-55 \\
20-25 \text { to } \\
35-40 \\
\text { Below } 20 \\
\text { or } 25\end{array}$ \\
\hline $\begin{array}{l}\text { American Psy- } \\
\text { chiatric Asso- } \\
\text { ciation DSM III }\end{array}$ & $\begin{array}{l}\text { Mental } \\
\text { Retarda- } \\
\text { tion }\end{array}$ & $\begin{array}{l}\text { Mild Mod- } \\
\text { erate } \\
\text { Severe } \\
\text { Profound }\end{array}$ & $\begin{array}{l}50-70 \\
35-49 \\
20-34 \\
\text { Below } 20\end{array}$ \\
\hline $\begin{array}{l}\text { World Health } \\
\text { Organization }\end{array}$ & $\begin{array}{l}\text { Mental } \\
\text { Subnor- } \\
\text { mality }\end{array}$ & $\begin{array}{l}\text { Mild } \\
\text { Moderate } \\
\text { Severe } \\
\text { Profound }\end{array}$ & $\begin{array}{l}50-70 \\
35-49 \\
20-34 \\
\text { Under } 20\end{array}$ \\
\hline
\end{tabular}

Bailey (1982) stated that the aspects of selfdetermination for students with intellectual disability include: self-helping, bathing, dressing and decorating, while Wehman and McLaughlin (1981) mentioned the domain's ability to care for themselves(selfcare_involving eating, dressing, toileting, grooming, safety, and health skills. In this research the selfdetermination of student with intellectual disability include: (1) Imparting knowledge about the how to take care of themselves; (2) Improving self-care skills; (3) Developing the habit of taking care of oneself; (4) Developing the ability in self-adjustment (Depdikbud, 1987).

Students with intellectual disability can be independent if they can perform activities without the help of others. Gonibala (1993) mentioned the services of guidance and counseling in special schools specifically for blind students are: a) data collection, b) the presentation of information, placement, c) assessment and research, d) follow-up, and e) references. Kartadinata (1988) stated that self-reliance becomes an essential goal in responsibility. Fallen and Umansky (1985) argued that self-reliance in children is manifested firmly in daily life. Ahman (1998) also stated self-reliance shows the percentage of most of the aspects of the development of other due to the concern of parent (over protection).

American Association on Mental Retardation (AAMR) mentioned that mental retardation refers to significant subaverage in general intelectual functioning which exist along with lack of adaptive behaviorand is manifested during the developmental period. Mental retardation refers to a level of functioning required in the society which is significantly above the average training procedures of superior assets in adaptive behavior manifested in life. The mentally retarded person is characterized by the level of ability that is needed in the training process for the person to learn, and not by limitations on what the person can learn. The level of functioning in people with mental retardation is determined by the availability of training technology and the amount of resources that the society is willing to allocate, not by significant limitations in biological potential (Lynch \& Hanson, 1992). Lynch and Hanson (1992) classified students with intellectual disability in the Terminology Used in Several Definitions of Mental Retardation, show in table 1.

Paris and Oka (1986) mentioned that students with intellectual disability showed more problems in the lack of attention compared to their peers who are not disabled. They tend to withdraw, be indifferent, get easily confused and have shorter attention.

\section{METHOD}

Elliot (1993) mentioned that action research integrates teaching and teacher development, curriculum development and evaluation, reasearch and philisophical reflection into a unified conception of a reflective educational practice. It is shaped by structures which transcend the power of any single individual to create a change. This structure is manifested in the selection, sequencing and organizing curriculum content; in the teaching process in which the content is delivered; in the ways students are socially organized, and in time and resources allocated and distributed in relation to the teaching task. Data collection techniques in this research included interview, observation, and documentation study. Nasution (1992) revealed the following:Actual basic service program used interviews and observation techniques. The disclosure of the causes for the guidance of self-reliance has not been successfully obtained by the interview with the class teacher.

\section{FINDINGS AND DISCUSSION}

\section{Findings}

Guidance of Self-determination Service for Students with Mild Intellectual Disability

Guidance of their own characteristics was done by teachers by giving guidance about the characteristics and explanations of the differences of gender in men and women as well as differences in general. The teacher explained the idea by showing the difference in clothing, haircuts, and accessories that are used.

Guidance of self-care were explained in several ways, such as: introducing how to eat and drink, preparing food at the dinner table, and helping to cook at the kitchen. According to the teachers' practice, the 
activities of eating and drinking are done every day by guiding students to use cups, glasses, pour the water into a glass, and drink with a straw. Sometimes teachers help students, facilitate and pay attention to the students when eating with a spoon and fork, eating decently, and eating with discipline.

Maintaining the cleanliness of body, environment, and health care is also another finding obtained from this research. According to the teacher's guide, the implementations are done by: 1) explaining gradually, 2) giving examples, and 3) asking the students to perform the activities. Moreover, the implementations of sports activities include communicating with parents about the sports equipment that will be used on the next day. Dressing up and using simple make up were done by: 1) introducing types of clothes, 2) assiting students to comb their hair and tidy their clothes, and 3) guiding them to use simple make up such as to use powder and hair oil. Knowing and avoiding all sorts of danger (such as knives, nails, needles, broken glass, scissors, and the danger of fire through explanation in front of the class). Caring for clothes and household items such as washing, sewing, and ironing as exemplified to the students.

Being familiar with the rules, and signs, and obeying traffic rules which are learnt together with the teachers. Shopping activities are done by taking the students to go shopping to buy snacks at mini-market around the school. The abilities to work with other people are showed by the teachers by playing with their peers at school. Recognizing service providers is also conducted by taking students to the post office, public phone, health clinic at school, and visiting the recreational area.

\section{Discussion}

Having self-determination has been proven to be succesful in improving the ability and competency of children with intelectual disability. A research by Chao (2018) found that there is a positive correlation between self-determination and individuals with intelectual disabilities. Avcioglu (2012) also conducted a smiliar program to the present research which was effective to improve students self-management skills.

Factors that Causes the Ine ffectiveness of the Guidance to Increase The Self-determination of Student with Mild Intellectual Disability

There areseveral factors which make the implementation of guidance become less optimal, such as: a) curriculum materials are difficult to be applied to the students who are physically weak, b) teachers find difficulties in determining materials which are in accordance with the conditions of the student, and c) a lot of the materials can be ignored and should be given to students in higher grades. To these problems, Schaffer and Marks (2008) suggest to incorparte movies in the teaching and learning activities to improve students' self-determination. Students can also be encouraged to create their own movies based on what they have learnt.

There are also factors asociated with the ability of teachers, including: a) too much materials, b) difficulty in adjusting the time, . and c) repeatition of the lesson. Factors related to the infrastructure and the facilities. The school needs a lot of facilities but the funds are limited.

\section{CONCLUSION}

Self-determintabation service in self-care include: self awareness, preparation for students to do selfcare, plannig daily activities, carrying out the activities orderly, taking decisions, and thinking positively. The causes which makes the guidance unsuccessful, are: Low IQ, hyperactivity, bullying, difficulty in choosing and determining materials, boredom because of monotonous learning, and intervention for student with mild intellectual disability.

\section{REFERENCES}

Ahman, (1998). Bimbingan Perkembangan: Model bimbingan dan Konseling di Sekolah dasar. Disertasi. PPS IKIP Bandung.

Avcioglu, H. (2012). The Effectiveness of the Instructional Programs Based on Self-Management Strategies in Acquisition of Social Skills by the Children with Intellectual Disabilities. Educational Sciences: Theory and Practice, 12(1), 345-351.

Bailey, R. D. (1982). Therapeutic Nursing for the Mentally Handicapped. Oxford University Press, New Yoork Toronto.

Chao, P. C. (2018). Using Self-Determination of Senior College Students with Disabilities to Predict Their Quality of Life One Year after Graduation. European Journal of Educational Research, 7(1), 1-8.

Depdikbud. (1987). Petunjuk Pelaksanaan Kurikulum SLB-C, Pedoman bimbingan dan Penyuluhan. Jakarta.

Elliot, J. (1993), Action Research for Educational Change. Open University Press, Milton Keynes, Philadelphia.

Fallen, H. N., \& Umansky, W. (1985). Young Children With Special Needs, Secon Edition, Charles E.

Gonibala, I. (1993). Karakteristik Bimbingan Konseling Di SLB-A. Tesis PPS IKIP Bandung. 
Kartadinata, S. (1983). Kontribusi Iklim Kehidupan Keluarga dan Sekolah Terhadap Adekuasi Penyesuaian Diri. Bandung: Tesis PPS IKIP Bandung.

Lynch, E. W., \& Hanson, M. J. (1992). Developing cross-cultural competence: A guide for working with young children and their families. Paul $\mathrm{H}$. Brookes Publishing.

Muro, J. J., \& Kottman, T. (1995). Guidance and counseling in the elementary and middle schools: $A$ practical approach. Brown \& Benchmark.
Nasution, S. (1992). Teknik Penelitian Naturalistik Kualitatif. Bandung: Remaja Rosdakarya.

Paris, S. G., \& Oka, E. R. (1986). Self-regulated learning among exceptional children. Exceptional children, 53(2), 103-108.

Schaffer, J., \& Marks, S. U. (2008). Promoting Slef Determination through a Movie Project. Journal of Teaching Exceptional Children Plus, 4(6), 1-12.

Wehman, P., \& McLaughlin, P. J. (1981). Program development in special education: Designing individualized education programs. McGraw-Hill Companies. 